\title{
The Option Value Of Patent Licenses
}

\author{
Tri Destanto \\ 175100067P \\ Fakultas Komputer, 448757151 \\ tridestanto@umitra.ac.id
}

\begin{abstract}
Patent valuation is one of the most relevant issues within the studies on the management of intellectual property rights. As firms rely more and more on external sources of innovation, the need for reliable measurements of what is traded becomes essential. Patent valuation is especially challenging primary because of the great uncertainty affecting their returns and for the lack of market-based data. The most recent and promising attempts in this research field have been developed within the real option theory (ROT), which recognizes the effect of uncertainty on patent value, and they have taken advantage of the increasing amount of information available about licenses. The aim of this paper is to propose and empirically test a valuation model of licensed patents based on ROT. According to our model, the initial fee paid by the licensee is considered analogous to the premium she is willing to pay to buy an option to commercialize the licensed patents in the future. A fundamental prediction of ROT is that this option value increases with volatility. In order analyze the relationship between volatility and the initial fee of the license, we assume that volatility is primarily determined by market and technological uncertainty. We analyse 105 patent licenses. The results of our regression model show that both market and technological uncertainty positively affect the initial fee paid for a patent license.
\end{abstract}

Keywords: patent valuation, licensing agreements, real options

Copyright statement: Please do not quote or reproduce without the permission of the authors. 


\section{A. INTRODUCTION}

The recent shift of firms to more open models of innovation based on collaboration and external sourcing of knowledge stands out as one of the most interesting phenomena characterizing the knowledge-based Economy (Kamiyama, Sheehan and Martinez, 2006). However, according to Arora and colleagues (2001) there are still many factors affecting the transaction costs involved in technology exchange. Among others, patent valuation makes the reach of a satisfactory agreement difficult for both the licensee and the licensor. In this regard, well functioning markets for technology require an improvement in the accuracy of any valuation attempts through the provision of "reliable valuation benchmarks" (Rivette and Kline, 2000: 62).

To date, there is an undesirable lack of reliable methods for valuing patents (Rivette and Kline, 2000; Reitzig, 2006; Kamiyama et al., 2006). As pointed out by Pitkethly (2006), the majority of works providing econometric methods of patent valuation generally deal with aggregate values rather than the individual patents. Further, even though some authors have tried to assess the value of patent as stand-alone based, for instance, on patent renewal data (Pakes and Shankerman, 1984; Pakes, 1986), citation data (Trajtenberg, 1990) or survey-based measure (Gambardella, Harhoff \& Verspagen, 2006), they only provide indirect measures or estimation of patent value.

According to Reitzig (2006), patent valuation is especially challenging because of the intangible nature of patents and the great uncertainty their returns are subject to. As a consequence, the most recent and promising attempts in patent valuation efforts have been developed within the real options theory (ROT), which potentially recognizes the effect of uncertainty on patent value in a more correct way. Indeed, starting out with Pakes (1986), the idea of valuing patents as real options has gained an increasing attention among scholars (e.g., Marco, 2005; Pitkethly, 2006; Li et al., 2007; Ziedonis, 2007). Nevertheless, there are still many caveats to the valuation of patents as real options that hinder the widespread application of this approach. For instance, the use of the choice of the appropriate option valuation model, the 
measurement of the option parameters and the empirical validation of ROT based model for patent valuation (Reitzig, 2006).

Some authors have tried to deal with these problems by using the increasing amount of information available on market-based licensing contracts (e.g. Miller and Bertus, 2005; Ziedonis, 2007). The rationale for this choice is twofold. First of all, licensing data provide more objective measures of patent value, based on market data (i.e., payment structure of the licensing contract). Second, the use of these data is consistent with the increasing evidence of the employment of such mechanisms to transfer patents among firms in industries, such as chemicals and pharmaceuticals, electrical, software and ICT (e.g., Grindley and Teece, 1997; Rivette and Kline, 2000; Annand and Khanna, 2000; Gu and Lev, 2001; Arora et al., 2001; Arora and Fosfuri, 2003; Kim and Vonortas, 2006).The aim of this paper is to test whether patent valuation within a patent licensing transaction is consistent with ROT. The work of Ziedonis (2007) has analyzed the use of option contracts and the adoption of real option reasoning by those firm licensing technologies from the University of California. Our paper offers several specific contributions. First, Ziedonis (2007) focuses on the licensing decision process whereas we analyze the value of the transactions. Second, we consider separately the effect of market and technological uncertainty since previous literature has reported that the two forms of uncertainty can have distinct effects (McGrath and Macmillan, 2002; Oriani and Sobrero, 2007; Anand, Oriani and Vassolo, 2007). Third, we analyze a cross-industry sample of patent licenses, where the licensor is not necessarily an academic institution, since academic licensing present specific characteristics (Jensen and Thursby, 2001). We will deal with these issues modelling the option created by the licensing contract for the licensee and conducting an empirical analysis based on a sample of 105 patent licenses. The paper is organized as follows. Next section will discuss the theoretical background, the model and the theoretical propositions. Section 3 will present the sample, the data and the variables, while section 4 will show the results of the empirical estimation. Finally, the last section will summarize and discuss the contribution of the paper. 


\section{THEORETICAL FRAMEWORK}

The application of valuation methods based on discounted cash flows, assuming investors' risk-aversion and the non changeability of the firms' actions once planned, normally fails to fully capture the value of highly uncertain and flexible investments (Kogut and Kulatilaka, 1994). More recently, the idea that investments in real assets create opportunities that are analogous to the options traded in the financial markets has been widely accepted by the literature (e.g. McGrath, 1997; Huchzermeier and Loch, 2001). Indeed, starting out with the pioneering studies of Myers (1977), ROT has had an increasing impact on research in strategic management and corporate finance. A main aspect of ROT is that any corporate decision to invest or disinvest in real assets can be conceived as a real option that ensures the firm a right, but not an obligation to take some action in the future (Trigeorgis, 1996; Kogut and Kulatilaka, 2001).

Accordingly, several ROT based models have been elaborated over time for the valuation of R\&D projects (e.g. Pennings and Lint, 1997; Perlitz, Peske and Shrank, 1999; Schwartz and Moon, 2000) and patents (Pitkethly, 2006). Since patents normally combine uncertain returns with high flexibility of use, their option nature can be easily appreciated. This is true either from the point of view of the patent holder or the potential patent receiver. Indeed, from the perspective of the technology holder the options embedded in the patent are basically two: the option to use that patent by her own or to license that patent to others. Symmetrically, from the point of view of the technology buyer, patent flexibility is related to the option to use or not the patent to commercialize the underlying technology and the eventual timing of use. However, to the best of our knowledge, existing work has mainly focused on the patent holder's point of view, whereas the perspective of the potential patent buyer has been investigated much less. Moreover, the empirical validation of real option valuation is very limited, mainly due to the difficulty of estimating the option valuation parameters. Zideonis (2007) has empirically analyzed the licensee's decision process, but not the licensee's valuation. The aim of this paper is to analyse the option value of patents as accrued to the licensee. In doing that, we will refer to the information provided by licensing contracts, as explained in the following paragraph. 


\section{Patent licensing}

The analysis of patent licenses is particularly useful to test the option value of patents since they represent a market-based transaction. Licenses could be granted for any type of intellectual property right (IPR), that is, for patents, trade secrets, trademarks, copyrights and so on. Among them, patent licenses are the most frequently used to exchange technologies. Specifically, patent licenses entitle the licensee (technology buyer) to use the patent rights and, in turn, they compel her to pay fees, royalties or both to the licensor (technology holder) on the bases of well defined payment scheme (Granstrand, 1999). The payment structure of a patent licensing contract is sketched in figure 1 .

Figure 1. The payment structure of a patent licensing contract

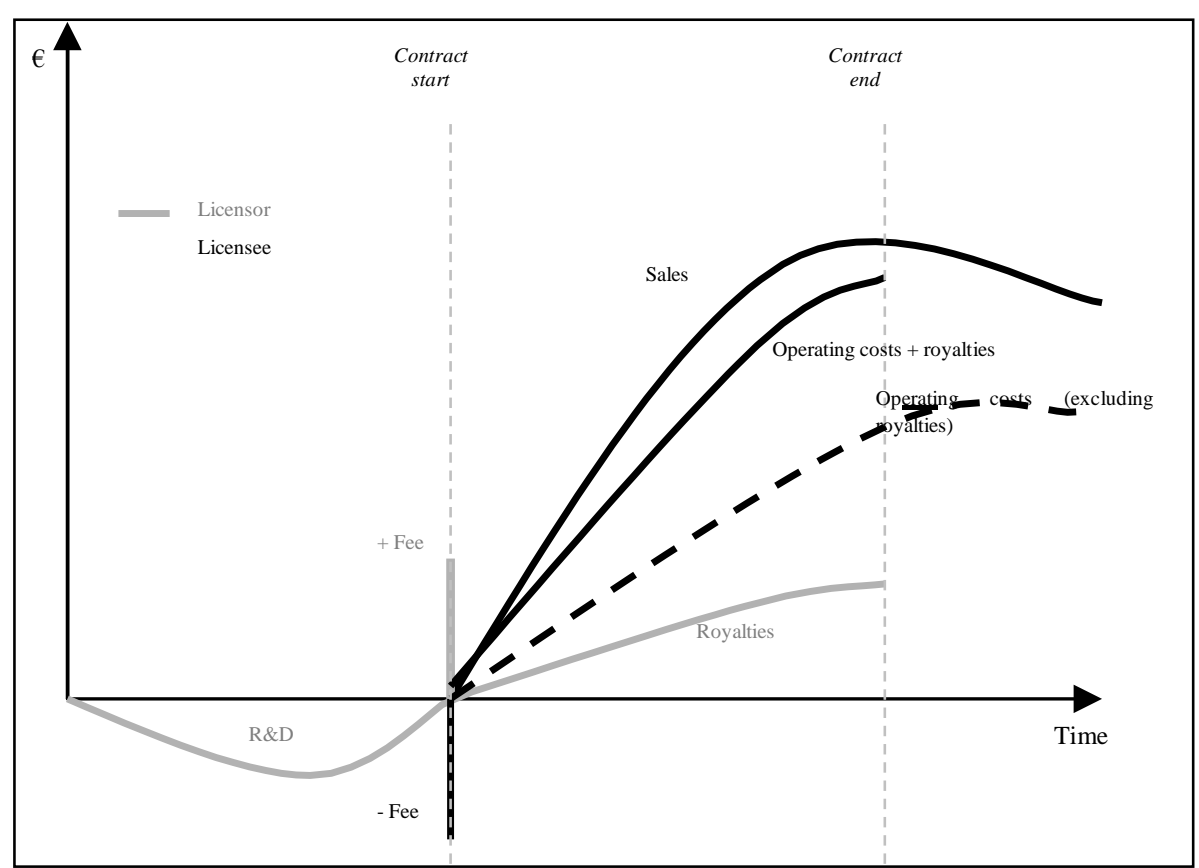

Source Granstrand (1999) 
The graphic shows the asymmetric condition of the licensor and the licensee before the start, during and after the end of any licensing contract. The underlying assumption is that the licensor does not compete with the licensee in the marketplace. Her stream of revenues, indeed, only stems from the flow of royalties periodically paid by the technology buyer. Instead, the payment and revenue structure of the licensee is more articulated. After the initial payment (up-front payment, down payment, initial fee), the licensee is given the right to fully exploit the licensed patent and thus she starts to produce and sell her products. In order to do that, the licensee sustains a certain amount of operating costs. Besides these costs, the licensee also has to periodically paid royalties (generally set as a percentage of sales) as a compensation for the use of the licensed patent.

Based on these considerations, it is no doubt that the value of license as perceived by the licensee depends on two important features of the contract: first, the duration or term of license that is equal to the number of years the licensee is allowed to exploit the licensed patents; second, the scope of the license conceived, instead, as the overall set of technologies, IPRs and know-how that are exchanged in the transaction. Starting from this baseline, there are also many other contractual provisions that make licensing agreements increasingly more sophisticated and diversified to the detriment of standardization and comparison. These clauses, indeed, affect the value distribution between the licensor and the licensee. Besides the two more common forms of value payments (the licensee agrees to pay to the licensor the up- front payment and the royalty rate namely), there are other many plausible elements making up the complex nature of the license remuneration scheme (see Razgaitis, 2003). Among them, the most significant are minimum annual royalties and milestones payments that are fixed cash payments due on each anniversary of the license or upon the crossing of some milestone events, respectively. As such, they stand as a guarantee of the commitment of the licensee to use her best efforts to bring the licensed technology to market and to continue to a best-efforts marketing program for the licensed technology throughout the life of the license agreement. Moreover, as already advanced, the parties may also agree on a certain number of contractual clauses that impact on the value of the license indirectly. The exclusive clause is one of the more relevant and intriguing examples 
at hand. Indeed, an exclusive license allows the licensee to fully exploit the licensed technologies without the threat that other licensee may bite the market to the detriment of her profitability.

\section{The proposed model}

Given their structure, patent licenses can be seen as options from the licensee's perspective. In fact, when entering a licensing contract, the licensee pays an initial fee (premium to buy the option) to acquire the right (option) to develop and commercialize the technology protected by the patent. In particular, the licensing contract is analogous to a financial call option. As a call option provides its owner with the right but not the obligation to buy an underlying financial asset at a predetermined exercise price before a given maturity date, the licensing contract provides the licensee with the opportunity to acquire the NPV of the cash flows from the commercialization of the patented technology (underlying asset) paying a development and industrialization cost (exercise price) at some time before the licensing term (maturity). Similarly to the underlying asset of a financial option, the NPV is subject to volatility over time, stemming from different sources of uncertainty.

The initial fee paid to enter the licensing contract is then a critical variable for ROT, since it should reflect the option valuation by the licensee. Following financial options literature (Black and Scholes, 1973), the initial fee paid by the licenses $(F)$, analogous to the premium paid to acquire a call option, can be expressed as a function of the following variables:

$$
\mathrm{F}=f\left[N P V, I, \sigma, n, r_{f}\right]
$$

where:

$N P V=\mathrm{NPV}$ of cash flows from technology commercialization

$I=$ Development and industrialization cost required for technology commercialization

$\sigma=$ Volatility of NPV

$n=$ term of the license

$r_{f}=$ Risk-free interest rate 
Assuming for the sake of simplicity no further investment after product commercialization and constant annual sales over the licensing period, based on the previous description of the economic structure of a patent license, the NPV can be expressed as follows:

$N P V=[S(1-o p c \%-r \%)] a_{n} \neg i$

[2]

Where:

$S=$ Annual sales from the licensed patent

opc\% = Incidence of operating costs on sales

$r \%=$ Royalty rate

$a_{n} \neg i=$ Rent factor for $n$

years and discount rate $i$

$=$ discount rate $($ different

from $r_{f}$ )

Based on the proposed model of valuation (expressions [1] and [2]), $F$ positively depends on NPV and then it is affected by the NPV determinants. Moreover, $F$ is positively influenced by the license term (maturity of the option) and risk-free interest rate.

The most interesting role within ROT is, however, plaid by volatility. A fundamental prediction of ROT is that the option value increases with volatility. This is because the downside is limited (premium paid for the option), whereas the upside has not an upper bound (e.g., McGrath, 1997; Kulatilaka and Perotti, 1998; McGrath and Nerkar, 2004; Ziedonis, 2007). If the licensee uses a ROT based model to determine how much she should pay to enter the license, we should then expect $F$ to increase with volatility.

In order to analyze the effect of volatility on $F$, we isolate the sources of uncertainty that affects volatility. We decompose uncertainty into the market and technological domains, as done by previous studies on real options (eg. MacMillan and McGrath, 2002; Oriani and Sobrero, 2007; Anand et al., 2007). Market uncertainty refers to 
the volatility of the potential demand for the patented technology. Technological uncertainty concerns the technical and manufacturing performance and feasibility of the patented technology (Huchzermeier and Loch, 2001; Ziedonis, 2007). This uncertainty critically affects the commercial potential of the licensed technology.

Based on that, we expect the following:

Proposition 1. The initial fee of a patent license increases with the degree of market uncertainty Proposition 2. The initial fee of a patent license increases with the degree of technological uncertainty

\section{DATA AND VARIABLES}

\section{Sample and data sources}

In order to address the aim of the paper we defined a research design based on license and patent data. For this purpose, as a result of a careful search process, we decided to rely on a database that seemed to better meet our requirements of analysis. We referred to the proprietary Intellectual Property database that has been developed by the Financial Valuation Group $(\mathrm{FVG})^{1}$ with the aim to conduct empirical research on intellectual property. This database is a compilation of intellectual property transactions gleaned from publicly available documents. Three primary criteria have been employed by FVG to select the transactions into the database: 1) each license had to involve the exchange of an IPR explicitly; 2) the transaction had been closed; 3) a certain payment structure was agreed upon by the parties, even if those monetary amounts were not disclosed (Financial Valuation Group, 2007). As such, this database records approximately 3,000 licensing agreements concluded from the 1970s to the present, including approximately 40 fields of information regarding such transactions. The dataset mainly includes US organizations. The information provided encompasses document sources, transaction dates, the names of the licensor and the licensee, their SIC and NAICS codes, the type of agreement, the number and the ID number(s) of the patent(s) licensed, a brief synopsis of the transaction, and a detailed description of the remuneration structure.

Since our analysis focuses on patent licenses, we excluded all licenses regarding IPRs different from patents (e.g. trademarks), coming out with an initial dataset of 
1,048 licensing agreements, including both technology and patent licenses, for the period 1970-2001. Starting from this sample, we needed al those licenses that disclosed both the details of the remuneration scheme and the number $o$ the patent(s) involved. We then decided to adopt the following two criteria to select the transactions for our final sample: 1) the license had to report the ID-number of the underlying patent(s);2) the license remuneration structure had to be disclosed and include the payment of an initial fee. This selection criteria decreases our data set to 137 licenses. The main reason of this undesirable cut of the number of licenses is that, due to the strategic relevance and competition sensitivity of licenses, the parties involved very often require a confidential treatment for most of the information included in such contract.

For each license in the new sample, we downloaded the original document from the SEC online website and from the proprietary Thompson Research Dataset in order to clearly identify the patents involved in the transaction. We also retrieved all patent documents from the publicly available sources of patent information (USPTO, Google Patent Search and Freepatentsonline). At the end we had a sample of 449

patents pertaining to 137 licenses. Data for these patents were gathered from the original patent documents and from the NBER database (see Hall, Jaffe and Trajtenberg, 2002). Finally, we gathered information on licensors and licensees from proprietary or publicly available data sources (among others, Thomson Research, Compustat and Datastream) and on market data at the industry level from the STAN database released by the OECD.

We finally needed to drop those licenses involving firms whose information about their sectors or their characteristics was not available. At the end we reached a final sample of 106 patent licenses. Table 1 and 2 show the distribution of these transactions per year and industry at the 2digit-SIC level. 
Distribution of Licenses per year

\begin{tabular}{|c|c|c|}
\hline Fres & Freq. Percen & Cum. \\
\hline 19901 & 1 & 0.94 \\
\hline 19912 & 1.89 & 2.83 \\
\hline 19924 & 3.77 & 6.60 \\
\hline 19938 & 7.55 & 14.15 \\
\hline 19947 & 6.60 & 20.75 \\
\hline 199518 & 16.98 & 37.74 \\
\hline 199625 & 23.58 & 61.32 \\
\hline 199728 & 26.42 & 87.74 \\
\hline 19986 & 5.66 & 93.40 \\
\hline 19995 & 4.72 & 98.11 \\
\hline $2000 \underline{2}$ & 1.89 & 100.00 \\
\hline 100 & 10 & \\
\hline
\end{tabular}

3.2. Variables and model specification

Distribution of Licenses per industry

\begin{tabular}{|c|c|c|}
\hline dig2sic Freq. & Percent & Cum. \\
\hline 122 & 1.89 & 1.89 \\
\hline 201 & 0.94 & 2.83 \\
\hline 221 & 0.94 & 3.77 \\
\hline 262 & 1.89 & 5.66 \\
\hline 2825 & 23.58 & 29.25 \\
\hline 302 & 1.89 & 31.13 \\
\hline 321 & 0.94 & 32.08 \\
\hline 333 & 2.83 & 34.91 \\
\hline 357 & 6.60 & 41.51 \\
\hline 3613 & 12.26 & 53.77 \\
\hline 373 & 2.83 & 56.60 \\
\hline 3828 & 26.42 & 83.02 \\
\hline 392 & 1.89 & 84.91 \\
\hline 492 & 1.89 & 86.79 \\
\hline 501 & 0.94 & 87.74 \\
\hline 672 & 1.89 & 89.62 \\
\hline 736 & 5.66 & 95.28 \\
\hline 802 & 1.89 & 97.17 \\
\hline $87 \underline{3}$ & 2.83 & 100.00 \\
\hline 106 & 100.00 & \\
\hline
\end{tabular}




\section{Dependent variable}

According to the model proposed, we needed the initial licensing fee as dependent variable, which we considered analogous to the premium paid by the licensee to buy a call option. To do so, we relied upon the data on the license remuneration structures. When the licensing contract is signed, the licensee is normally required to make an up-front payment, generally in the form of cash payment due within the first days of the license life. It represents the first "use it or lose it" clause in any licensing agreement. From the point of view of the licensor, she requires this payment as a proof of the licensee's commitment in the deal. From the point of view of the licensee, instead, it should reflect the amount of money (premium) she is willing to pay in order to buy the option to develop and commercialize the innovation protected by licensed patents. The measure of the amount of the initial fee paid in U.S. dollars by the licensee is available at the level of each licensing contract examined in this study. Since this variable does not follow a normal distribution, as required by the OLS regression model, we took the natural logarithm of the values in order to achieve an approximation of this distribution.

\section{Independent variables}

In order to analyze the impact of volatility on the option value of patent licenses, we decomposed uncertainty into the market and technological domains, as done by previous studies (eg. MacMillan and McGrath, 2002; Oriani and Sobrero, 2007; Anand et al., 2007).

Market uncertainty refers to the potential demand for the licensed technology. An often used measured of market uncertainty is the volatility of the expected demand for the technology underlying the patent license. Thus, consistently with previous research (e.g., Folta and O'Brien, 2004), we measured such variable as the standard deviation of the market growth rate from year $t-3$ to year $t$ (the year of the license). ${ }^{2}$ In doing so, we encountered two different problems related to the choice of the countries and the industries the market volatility refer to. First, since licensee is allowed to exploit the licensed patents in different territories, under the territorial restrictions clause included in the license, we had to account for the volatility of the expected demand in all these territories. However, for few licenses we were not able 
to know the exact number of countries involved, so we decided to collect data referring only to the U.S. market, since patents in our sample are granted by the USPTO and thus are in force at least in the U.S. The second problem concerned the choice of the industry. For the sake of simplicity, we decided to refer to the licensee's industry, as identified by the NAICS code or corresponding ISIC code, by collecting information at the 3-digit level. In this way we did not take into account any diversification effect pursued by the licensee. Indeed, licensed product might be sold in markets different from the licensee market.

Technological uncertainty is related to the technical and manufacturing feasibility of the patented technology, which ultimately affects its commercial potential (Huchzermerier and Loch, 2001; Ziedonis, 2007). This may depend on how much distant the licensed technology is from the commercialization stage. Accordingly, following previous studies (Lanjouw and Shankerman, 2001; Ziedonis; 2007), we measured this variable using the number of backward citations contained in the USPTO patents to previous USPTO patents. Each patent cites previous patent that represent the stat of the art at the moment of the patent grant. The number of backward citations is a measure of the newness of the patented technology. The idea is that when there is less prior art to be cited, there is higher technological uncertainty and the commercial potential of the technology is higher (Ziedonis, 2007).

In order to get this information, we merged our dataset with the NBER dataset that collects data on USPTO patents from January 1, 1963 through December 30, 2002 (see Hall et al., 2002, for a detailed description of the database). Since technological uncertainty increases when the number of backward citations decreases, we calculated our measure of technological uncertainty multiplying the number of backward citations by -1 . When the license involved the exchange of more than one patent, we calculated the mean of this variable in order to account for the average technological uncertainty associated to the overall set of patents licensed.

\section{Control variables}

The most relevant negotiation issue that rises before the conclusion of a license refers to the level of the royalty rate the licensee will be required to pay to the 
licensor at each anniversary of the license. The common base for the calculation of the annual royalties is the annual amount of net sales regarding the licensed products. According to our model (expression [2]), this variable negatively affects the initial licensing fee since it reduces the NPV of the license. We measured such a variable as the percentage royalty rate reported in each licensing agreement. As anticipated earlier, besides royalties, another form of

\footnotetext{
${ }^{2}$ We also calculated the standard deviation over a longer period (4 and 5 years), but the results did not substantially change.
}

value payments due to the licensor is represented by the milestone payments that are fixed cash payments due upon the crossing of some milestone events. They could negatively impact on the price the licensee agrees to pay for the option since they reduce the flexibility of the licensee in the use of the license. We then calculate a dummy equal to 1 if milestone payments are due and 0 otherwise.

We also control for term of the license that affect positively the value of the patent for the licensee since a longer license allows her to increase the profits from the licensed patents (Parr and Sullivan, 1996). The term or duration of license is computed as the residual number of years the license is in force.

We also account for the effect played by the growth rate of industry. According to Fosfuri (2004), an increasing market growth may dump the rent dissipation effect for the licensor - the propensity to license out her technologies would be greater, other things being equal - since the competition in that market would be less fierce. From the point of view of the licensee this means that she would be more prone to pay a greater amount of money for an option that gives her the chance to face a lower competition and thus to better exploit the licensed patents. We control for this variable by calculating the growth rate of industry output for a period of time ranging from year $t-3$ to year $t$.

Moreover, since some licenses include more than one patent, we include a measure of license scope calculated as the number of the patents involved in the transactions. ${ }^{3}$ Another important measure that could affect the value of the license is its geographic scope. It refers to the number of national territories in which the licensee is allowed to exploit the licensed patents. The computation of this measure 
left us to handle an important issue. Since geographic scope of license is strictly tied to the patent family size ${ }^{4}$ (number of jurisdictions in which the patent is in force) this required us to take into account both. By comparing them, we decided to take the maximum value between the family size of the licensed patents and the geographic scope of the license because this value may reflect better the overall market potential of the license.

In order to account for the appropriability regime and the effectiveness of patent protection and transactions (Kim and Vonortas, 2006), we adopted the distinction between "complex" and "discrete" product industries made by Cohen, Nelson and Walsh (2000). According to the authors, patent licenses should more effective in industries characterized by a discrete technology. In particular, following Cohen and colleagues (2000), we defined a dummy equal to 1 if the licensee's 2-digit SIC is equal to or above 35 and 0 if the SIC is below.

The value of patent licenses should also be affected by the exclusive clause. Exclusive license allows the licensee to exploit the licensed technologies without bearing the competition of other licensees in the market. Its effect on the initial fee is not clear a priori. In fact, the traditional view of patent licensing holds that licensee firms prefers to an exclusive license to get the maximum outcome from the licensed patent (Parr and Sullivan, 1996). Everyone can agree on saying that competition will be lower and than the

\footnotetext{
${ }^{3}$ The fact that the licensee includes more than one patent may not imply that these patents can be exploited separately depending on the licensee convenience. It may depend on the fact that licensed products are more or less complex and therefore more or less difficult to be commercialized.

${ }^{4}$ For the computation of this value we relied on the procedure used by Hall, Thoma and Torrisi (2006)
}

exclusive licensee can take advantage of the overall market potential associated to the licensed product. Nevertheless, more recently some authors have pointed out that licensee firms might want to be licensed openly in order to "...prevent, or at least retard, the commercial development of inventions in a particular area" (Agrawal and Garlappi, 2007: 2). This is the case of firms whishing to sponsor particular laboratories - research institution and university- that require to be licensed on a non-exclusive basis only in order to purposely affect the incentives of 
other - competitive- firms to embark on technological trajectories that are not favourable to them. We control for this effect including a dummy equal to 1 and 0 otherwise.

Studies on patent valuation based on patent data (e.g. Trajtenberg, 1990; Harhoff, Scherer and Vopel, 1999; Reitzig, 2002, 2004) have shown that the value of a patent, in terms of its technological importance and quality, can be proxied by the number of forward citations the target patent has received since its grant to date. Since this is a relative measure of such value, depending on how far is the time of its grant from our point of observation, we control for this value by counting the number of citations received till the date of the license. As already anticipated, since some licenses involve more than one patent, we calculate the mean value of this variable. Finally, we accounted for the influence of the identity and nature of the licensor on the initial fee building two dummy variables. The first one is equal to 1 if the licensor is a non-profit organization - University, University or Public Research Fundations -, 0 otherwise. The second variable is 1 if she is an individual (generally, the inventor), 0 otherwise.

\section{Descriptive statistics and correlations}

In Table 3 we report descriptive statistics for each variables included in the equation we estimated. Some interesting points are worth being mentioned. First, the scope of license that reflects the number of patents involved in each transaction sets its mean at around 3. This value is relatively low if compared to the maximum that is 39. This would mean that the majority of licenses imply the exchange of very few patents, generally only one. The distribution is considerably right skewed. Second, the values associated to the term of the license are also very interesting. They show that the average duration of a license is 15 years. Patvalu priorlic captures the number of citations received by the licensed patents until the time of license conclusion - this measure would represent the value of patent as perceived by the licensee. A standard deviation of 16 suggests that licensed patents differ very much in their perceived value. The most valued patent indeed records 113 citations against 0 citation of the less-cited patent ever. The same reasoning applies also for our independent variable called TechUncert that exhibits substantial dispersion 
ranging from 0 to 213. Again, since this variable reflects the newness of patented technologies, in terms of citation made to other previous patents - this measure assess the distance of the patented technology from the prior state of art- these values suggest that licensed patents differ very much in their radicalness

\section{Descriptive Statistics of Variables}

\begin{tabular}{|rllll|}
\hline \multicolumn{1}{|c}{ Mean } & & S.D. & Min & Max \\
\hline Upfront 12,6365 & 2,344 & 8,0064 & 18,7134 \\
Royalty 0,0293 & 0,0314 & 0 & 0,12 \\
Scope 3,283 & 5,8971 & 1 & 39 \\
Term 15,3236 & 6,3564 & 1 & 40 \\
Patvalue priorlic 7,8453 & 16,0986 & 0 & 113 \\
Milestpayms 0,1132 & 0,3184 & 0 & 1 \\
Excl 0,6415 & 0,4818 & 0 & 1 \\
Nonprof 0,066 & 0,2495 & 0 & 1 \\
Indiv 0,1604 & 0,3687 & 0 & 1 \\
Growthrate 5,9416 & 7,8395 & $-53,89$ & 20,3 \\
Geograph 3,5377 & 5,5792 & 1 & 31 \\
Complex 0,5566 & 0,4991 & 0 & 1 \\
MarketUncert 5,0337 & 11,7143 & 0,1866 & 104,265 \\
TechUncert 15,0626 & 27,7489 & 0 & 213,5128 \\
\hline
\end{tabular}


Table 4 shows bivariate correlations among all variables included in the regression analysis. From the analysis of Table 4 no serious problems of multicollinearity emerge.

\section{Variables Correlation Matrix}

\begin{tabular}{|c|c|c|c|c|c|c|c|c|c|c|c|c|c|c|}
\hline & 1 & 2 & 3 & 4 & 5 & 6 & 7 & 8 & 9 & 10 & 11 & 12 & 13 & 14 \\
\hline 1 Upfront & 1 & & & & & & & & & & & & & \\
\hline 2 Royalty & $-0,485$ & 1 & & & & & & & & & & & & \\
\hline 3 Scope & 0,2519 & $-0,1244$ & 1 & & & & & & & & & & & \\
\hline 4 Term & 0,1643 & $-0,1125$ & 0,1176 & 1 & & & & & & & & & & \\
\hline 5 Patvalue priorlic & 0,0857 & $-0,0735$ & 0,0125 & $-0,2318$ & 1 & & & & & & & & & \\
\hline 6 Milestpayms & $-0,156$ & 0,0361 & $-0,0122$ & 0,0288 & 0,0292 & 1 & & & & & & & & \\
\hline 7 Excl & $-0,3056$ & 0,1792 & $-0,0746$ & 0,2114 & $-0,2378$ & 0,205 & 1 & & & & & & & \\
\hline 8 Nonprof & $-0,2339$ & 0,1271 & $-0,0387$ & 0,1725 & $-0,1203$ & 0,1448 & 0,1988 & 1 & & & & & & \\
\hline 9 Indiv & $-0,3203$ & 0,075 & $-0,1437$ & 0,0264 & $-0,1201$ & $-0,1562$ & 0,1123 & $-0,1162$ & 1 & & & & & \\
\hline 10 Growthrate & $-0,0003$ & 0,1234 & $-0,436$ & $-0,0402$ & $-0,0203$ & 0,0503 & 0,0108 & 0,0344 & 0,003 & 1 & & & & \\
\hline 11 Geograph & 0,1483 & $-0,0539$ & 0,6093 & 0,1595 & $-0,0305$ & $-0,0024$ & $-0,1047$ & $-0,0189$ & $-0,126$ & $-0,273$ & 1 & & & \\
\hline 12Complex & $-0,0897$ & 0,0601 & $-0,1123$ & $-0,0243$ & 0,1678 & 0,0792 & $-0,0336$ & 0,0079 & 0,131 & 0,0406 & 0,0351 & 1 & & \\
\hline 13MarketUncert & 0,1429 & 0,0842 & 0,2141 & 0,135 & 0,2227 & $-0,0715$ & $-0,0281$ & $-0,0436$ & 0,056 & $-0,2377$ & 0,1828 & 0,0727 & 1 & \\
\hline 14TechUncert & 0,0659 & $-0,1154$ & 0,7262 & 0,0898 & 0,0003 & $-0,019$ & $-0,0678$ & $-0,0538$ & $-0,053$ & $-0,4159$ & 0,5724 & $-0,105$ & 0,2064 & \\
\hline
\end{tabular}




\section{RESULTS}

In Table 5 we report the results of the OLS regression of the log of the initial licensing fee on the uncertainty variables and the other control variables. In model 1 we introduce all the independent variables, with the exception of market and technological uncertainty, which are included in model 2.

\section{Results. Dependent variable: $\log$ (initial} licensing fee)

\begin{tabular}{|c|c|c|c|c|}
\hline & Model 1 & & Model 2 & \\
\hline Royalty rate & $\begin{array}{l}-27,96 \\
{[5.86]}\end{array}$ & 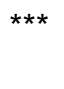 & $\begin{array}{l}-30,58 \\
{[5.73]}\end{array}$ & $* * *$ \\
\hline License scope & $\begin{array}{l}.084 \\
{[.041]}\end{array}$ & ** & $\begin{array}{l}.130 \\
{[.046]}\end{array}$ & $\star \star \star *$ \\
\hline License term & $\begin{array}{l}.072 \\
{[.030]}\end{array}$ & ** & $\begin{array}{l}.057 \\
{[.029]}\end{array}$ & * \\
\hline Forward citations & $\begin{array}{l}.001 \\
{[.011]}\end{array}$ & & $\begin{array}{l}-.006 \\
{[.011]}\end{array}$ & \\
\hline Milestone payments & $\begin{array}{l}-1.008 \\
{[.579]}\end{array}$ & * & $\begin{array}{l}-.900 \\
{[.559]}\end{array}$ & \\
\hline Exclusive & $\begin{array}{l}-.817 \\
{[.405]}\end{array}$ & ** & $\begin{array}{l}-.818 \\
{[.390]}\end{array}$ & $* *$ \\
\hline Non-profit institution & $\begin{array}{l}-1,864 \\
{[.743]}\end{array}$ & ** & $\begin{array}{l}-1,831 \\
{[.715]}\end{array}$ & $* *$ \\
\hline Individual licensor & $\begin{array}{l}-1,898 \\
{[.507]}\end{array}$ & $\star \star \star *$ & $\begin{array}{l}-1,887 \\
{[.492]}\end{array}$ & $* \star \star$ \\
\hline Market growth rate & $\begin{array}{l}.045 \\
{[.025]}\end{array}$ & & $\begin{array}{l}.046 \\
{[.025]}\end{array}$ & \\
\hline Geographic extension & $\begin{array}{l}-.022 \\
{[.041]}\end{array}$ & & $\begin{array}{l}-.004 \\
{[.040]}\end{array}$ & \\
\hline Complex technology & $\begin{array}{l}-.011 \\
{[.368]}\end{array}$ & & $\begin{array}{l}-.081 \\
{[.356]}\end{array}$ & \\
\hline Market Uncertainty & & & $\begin{array}{l}.036 \\
{[.016]}\end{array}$ & $\star \star$ \\
\hline Technological Uncertainty & & & $\begin{array}{l}.020 \\
{[.009]}\end{array}$ & $\star \star$ \\
\hline Constant & $\begin{array}{l}12,94 \\
{[.63]}\end{array}$ & $* * *$ & $\begin{array}{l}13,24 \\
{[.61]}\end{array}$ & $* * *$ \\
\hline $\mathrm{N}$ & 106 & & 106 & \\
\hline r2 & .475 & & .525 & \\
\hline $\begin{array}{l}\text { r2_a } \\
{ }^{*}: \mathrm{p}<.1,{ }^{* *}: \mathrm{p}<.05,{ }^{* * *}: \mathrm{p}<.01\end{array}$ & .414 & & .457 & \\
\hline
\end{tabular}


Model 1 shows that several characteristics of the licensing contracts significantly affect the initial licensing fee. As expected, the initial fee is negatively related to the royalty rate and positively related to the number of licensed patents (license scope) and the license term. A higher market growth rate also determines a higher licensing fee (the coefficient is positive and statistically significant at the $10 \%$ level). The presence of milestone payments significantly reduces the initial fee, presumably because it limits the licensee's flexibility and it increases her future outlays. Moreover, exclusive licenses have lower initial fees (the coefficient is negative, .817 , and statistically significant at the $5 \%$ level). This result is consistent with the recent insights provided by some authors (Agrawal and Garlappi, 2007) suggesting that under certain circumstances firms may even require to be licensed on a nonexclusive basis and then may attribute more value to non-exclusive patent licenses instead of exclusive ones. It is also interesting to notice that the licensing fee required by non-academic institutions and individuals are significantly lower than the those required by firms. While in the latter case this effect can be explained by a lower negotiating power, in the case of non-academic institutions it can be due to the fact that they have the main goal of diffusing the technology rather than making economic profits on it (Ziedonis, 2007). Finally, the number of citations received by the patent at the licensing date does not seem to matter. The same is true for the nature of technology (the coefficient of the variable 'complex' is not significantly different from zero).

In model 2 we introduce the variables of market and technological uncertainty. As predicted by our propositions 1 and 2, they both have a positive and statistically significant effect (at the 5\% level of confidence) on the initial licensing fee. This means that, consistently with ROT, the licensees is available to pay a higher price to enter a licensing contract when the downstream market is more volatile and the technological potential of the patented innovation is higher. No remarkable change are observed in the coefficients of the other variables (only the coefficient of milestone payments looses significance at the conventional level of $10 \%$ ). 


\section{B. CONCLUSION}

As competition pace is increasing and products are becoming more and more complex relying on a greater number of separately patentable elements, the need to increase the efficiency of markets for technology becomes essential. One way to do so is to promote an improvement in the accuracy of any valuation attempts through the provision of "reliable valuation benchmarks" for patent transactions (Rivette and Kline, 2000: 62). Although there is still an undesirable lack of valuation models, several insights have been provided by the developments of ROT. Since patents are characterized by uncertain returns and flexibility of use, the adoption of ROT to assess their value seems to be very suitable. Furthermore, recent work has looked with a growing interest at the increasing amount of information provided by the market- based patent licensing agreements (e.g., Ziedonis (2007).

Following this line of reasoning, the aim of this paper has been to explore the use of ROT for patent evaluation within licensing agreements. Accordingly, we have argued that the initial fee paid by the licensee to sign the licensing agreement can be considered analogous to the premium paid to buy a call option in the financial markets. The licensing agreements, in fact, provides the license with the right (option), but not the obligation, to develop and commercialize the technology protected by the patent. Based on this framework, we predicted that the initial licensing fee should increase with the degree of technological and market uncertainty affecting the transaction.

Empirically, we defined a research design based on patent and license data. We analyzed a sample of 106 licensing agreements. The results of our regression model supported our predictions. Both market and technological uncertainty positively affect the initial licensing fee. This result suggests that the licensee recognizes an option value in the license and she is available to pay more to enter the contract when uncertainty is greater. In fact, in presence of higher uncertainty, her upside potential gain is higher whereas her downside is still limited to the payment of the initial fee. This result supports the use of ROT based model in evaluating patents within licensing agreements. 
We have, however, to acknowledge an important limitation of the paper. We are not able to measure all the variables that should be used in a closed option valuation formula. The level of detail required, for example, to determine the strike price (investment for industrialization and commercialization) or the NPV does not allow to calculate these variables for a broad and cross-industry database. Therefore, we have decided not to estimate a closed option valuation formula, but to test the presence of a real option logic in the valuation of the license. Indeed, this is a limitation shared by all the empirical studies trying to test ROT (Lander and Pinches, 1998; Adner and Levinthal, 2004). Notwithstanding that, we believe that our study can encourage new work on the application of ROT to patent valuation. 


\section{ACKNOWLEDGEMENT}

University Of Indonesia University Of Mitra Indonesia

Telkom University

University Of Mellbourne

Saitama University 
D. REFERENCE $($ Based ISO 690 )

[1] A. S. Putra And O. M. Febriani, "Knowledge Management Online Application In Pdam Lampung Province," In Prosiding International Conference On Information Technology And Business (Icitb), 2018, Pp. 181-187.

[2] A. S. Putra, O. M. Febriani, And B. Bachry, "Implementasi Genetic Fuzzy System Untuk Mengidentifikasi Hasil Curian Kendaraan Bermotor Di Polda Lampung," J. Sist. Inf. Dan Manaj. Basis Data, Vol. 1, No. 1, Pp. 21-30, 2018.

[3] O. M. Febriani And A. S. Putra, "Sistem Informasi Monitoring Inventori Barang Pada Balai Riset Standardisasi Industri Bandar Lampung," J. Inform., Vol. 13, No. 1, Pp. 90-98, 2014.

[4] Putra, Arie Setya. "2018 Artikel Struktur Data, Audit Dan Jaringan Komputer." (2018).

[5] Putra, A. S. (2018, July 17). Paperplain Fundamental Create Application With Borland Delphi 7.0 University Of Mitra Indonesia. Retrieved From Osf.Io/Pbrn9.

\section{E. REFERENCE(Based APA )}

Putra, A. S., Aryanti, D. R., \& Hartati, I. (2018, November). Metode SAW (Simple Additive Weighting) sebagai Sistem Pendukung Keputusan Guru Berprestasi (Studi Kasus: SMK Global Surya). In Prosiding Seminar Nasional Darmajaya (Vol. 1, No. 1, pp. 85-97).

Sari, D. P., Febriani, O. M., \& Putra, A. S. (2018, November). Perancangan Sistem Informasi SDM Berprestasi pada SD Global Surya. In Prosiding Seminar Nasional Darmajaya (Vol. 1, No. 1, pp. 289-294).

Putra, A. S. (2018). Paperplain: Execution Fundamental Create Application With Borland Delphi 7.0 University Of Mitra Indonesia.

Putra, A. S., Sukri, H., \& Zuhri, K. Sistem Monitoring Realtime Jaringan Irigasi Desa (JIDES) Dengan Konsep Jaringan Sensor Nirkabel. IJEIS (Indonesian Journal of Electronics and Instrumentation Systems), 8(2), 221-232.

Darmawan, A., Yuliawati, D., Marcella, O., \& Firmandala, R. (2016). Sistem Absensi dan Pelaporan Berbasis Fingerprint dan SMS Gateway. EXPLORE, 7(1).

Febriani, O. M., Wahyuni, T., \& Yusuf, S. (2017). DESIGN OF WEBSITE-BASED INFORMATION SYSTEM FOR EDOCUMENT ADMINISTRASI IN THE COMMUNITY SERVICE UNIT (A Case Study at Rajabasa District). INTERNATIONAL JOURNAL OF COMPUTERS \& TECHNOLOGY, 16(7), 7010-7020. 
Febriani, O. M., \& Wahyuni, T. (2017, October). PERANCANGAN SISTEM E-DOCUMENT ADMINISTRASI LOGBOOK PENELITIAN PADA UNIT LAYANAN DI BANDAR LAMPUNG. In Prosiding Seminar Nasional Darmajaya (Vol. 1, No. 1, pp. 187-194).

Febriani, O. M., \& Permadi, A. B. (2017). Implementasi Sistem Aplikasi Data Bimbingan dan Pelanggaran Siswa pada Sekolah Menengah Atas di Lampung Tengah dengan Metode Analisis dan Desain Sistem Terdistribusi (SSAD). EXPERT, 7(1).

Febriani, O. M., \& Ambarwati, L. (2015). PERANCANGAN APLIKASI PENGOLAHAN DATA PENJUALAN UKM KELANTING KHAS TELO DESA SIDOHARJO KECAMATAN JATI AGUNG KABUPATEN LAMPUNG SELATAN. Jurnal Teknologi Informasi dan Bisnis Pengabdian Masyarakat Darmajaya, 1(1), 77-95.

Febriani, O. M. (2015). Rancang Bangun Aplikasi Ecommercemenggunakan Freewebstore pada UKM Kelanting di Desa Sidoharjo Lampung Selatan. Prosiding Sembistek 2014, 1(02), 446-458. 